\title{
Price Discovery and Memory Effects in Infant African Stock Markets: Evidence from Tanzania
}

\author{
Benedicto Kulwizira Lukanima ${ }^{1}$ \\ ${ }^{1}$ School of Business, Mzumbe University, Tanzania \\ Correspondence: Benedicto Kulwizira Lukanima, School of Business, Mzumbe University, Tanzania. E-mail: \\ bklukanima@mzumbe.ac.tz
}

Received: September 11, 2014

Accepted: September 24, 2014

Online Published: October 25, 2014

doi:10.5539/ijef.v6n11p36

URL: http://dx.doi.org/10.5539/ijef.v6n11p36

\begin{abstract}
This paper examines the price discovery mechanism at the Dar es Salaam Stock Exchange (DSE) in Tanzania. The objective is to explain the efficiency of price discovery in relation to its dynamics and deterministic market features, using the All Sector Index (ASI). Our results provide evidence of inefficient price discovery at the Exchange, associated with some moments of structural shifts. Moreover, the inefficient price discovery is corroborated by the fact that the Index does not follow a random walk. These finding are consistent with our investigation of the main features of the market: inactive trading, illiquidity, high dependence on foreign investors to boost market activities, investors' dependence on dividend as the main source of income rather than stock trading, uncompetitive trading among brokers, and motives for more returns from alternative portfolio investments in government securities. Generally, the findings have strong implications for market participants and policy makers at the DSE and similar markets.
\end{abstract}

Keywords: Africa, infant stock markets, market features, price discovery, random walk, Tanzania

\section{Introduction}

One of the core functions of stock markets is to facilitate price discovery (DSE Handbook, 2010), in which market forces, through interactions between buyers and sellers, determine stock prices. Theoretically, price discovery is expected to be a dynamic process, characterized by a fast equilibrium adjustment mechanism in which the arrival of information drives prices into that equilibrium (see Schreiber \& Schwartz, 1986; Baillie, Booth, Tse, \& Zabotina, 2002; Lehmann, 2002). Essentially, the dynamics of price discovery for an asset depends on several factors such as: the market characteristics like transaction costs and liquidity (O'Hara, 2003); the speed and frequency of trading activities (Brogaard, Hendershott, \& Riordan, 2012); the institutional structure of the market; alternative trading venues; and alternative investment opportunities (Hasbouck, 1995).

In essence, market discovery can be elaborated by the traditional financial theories of market efficiency and random walk (Dharmanesa \& Bessler, 2004), which can be understood through examining the distribution and memory effects of asset prices. On Tanzania, the literature does not offer evidence on the distribution of stock returns at the only stock exchange (DSE) in relation to its stock index structure. However, some news headlines can be a good starting point to understand the main features of the DSE. Table 1 summarizes some of the common news headlines, from which it is possible to deduce the following characteristic features: inactive trading, investors' dependence on dividend as the main source of income rather than stock trading, uncompetitive trading among brokers, high dependence on foreign investors to boost market activities, a few number of actively traded stocks, and illiquidity. Although there is no empirical evidence to affirm these characteristic features, they roughly signify market inefficiency.

In finance, the understanding of stock market behaviors has been made possible through different approaches. The Efficient Market Hypothesis (EMH) is one of the fundamental explanations of market behavior. Formalized by Fama (1965), the EMH technically states that the market is a martingale (fair game); hence information cannot be used to make profits. The cardinal philosophy of EMH is that all assets are priced so that all public information, both fundamental and price history, is already discounted in the prevailing market prices (Fama, 1970). Therefore, the only driver of price movements is new information or event. It follows that, if the market is efficient (prices carry all the information), no one is able to outperform it by market gaming because all investors are assumed to be rational and will ensure that the prices are fair. Investors, thus, make decisions after digesting 
the information and assessing the risks involved. Consequently, their collective consciousness of the market ensures equilibrium in the pricing mechanism. The theoretical explanation of equilibrium is that only today's information is important in making changes in today's prices. That is, today's prices are not related to yesterday's prices.

If stock prices are independent, they should follow a random walk and become unpredictable (Fama, 1998). Consequently, a normal probability distribution is achieved if there is enough collection of independent price changes, as the number of observations approaches infinity. From this normality assumption, emerges a large spectrum of statistical approaches to analyze asset price behavior, including the random walk version of the EMH. However, it is important to emphasize on the antagonistic implications of the two price behaviors: that is, market efficiency does not necessarily imply a random walk, but a random walk implies market efficiency. Hence, efficient markets do not necessarily guarantee normality of return distribution.

Further theoretical assertions categorize market efficiency into three categories: weak form, strong form and semi-strong form (Lorie \& Hamilton, 1973). These forms provide a more practical explanation for the drivers of randomness. The strong form asserts that prices already reflected "all that is knowable", or all public and private (insider) information. The weak form postulates that prices reflect only past price histories. Therefore, market efficiency is explained by the historical independence of prices, which may follow a random walk. Semi-strong form posits that prices only reflect public information. Therefore, it suggests that price randomness is not caused by the price series itself, but by outside influences such as security analysts. Hence, markets are said to be efficient simply because their prices reflect all public information.

The random pricing process can also be linked to some deterministic processes in a security market. This linkage is explained by a phenomenon referred to as chaos (Baren, 1994; Campbell, Lo, \& MacKinlay, 1997). In a deterministic system, chaotic dynamics can amplify small changes, thereby producing unpredictable behaviors in long run. Thus, whereas it is almost impossible to make long-term prediction, it is possible to make accurate short-term predictions. Hence, chaos has both good and bad implications for the prediction problem. The ability to predict the future is an important input for all decision makers in security markets. Conventionally, the ability to predict is a function of availability of information and prediction techniques. This conventional position is contradicting the chaos theory, which considers unpredictability as an inherent attribute of a wide range of phenomena. Hence, predicting is regarded as a fruitless exercise because it would be impossible to know and monitor all the variations that might have a significant effect on price changes.

Table 1. Characteristic features of the Dar es Salaam stock exchange

\begin{tabular}{|c|c|c|}
\hline Headline & News Media & Main Issue (Reporter) \\
\hline $\begin{array}{l}\text { Cross-listed shares seem } \\
\text { dormant at Dar Bourse }\end{array}$ & Daily News & $\begin{array}{l}\text { Cross-listed shares at DSE are hardly traded because they are properly prices at } \\
\text { home and there is lack of communication (Elinaza, 2013) }\end{array}$ \\
\hline $\begin{array}{l}\text { Stockbrokers Blamed for } \\
\text { Creating 'Fake' Liquidity }\end{array}$ & Daily News & $\begin{array}{l}\text { The Capital Markets and Securities Authorities (CMSA) blames stockbrokers for } \\
\text { "creating artificial liquidity by posting shares on the "all or none" board thus } \\
\text { preventing locals from buying even a fraction of such stocks (Elinaza, 2012). }\end{array}$ \\
\hline $\begin{array}{l}\text { Stockbrokers Push for Law } \\
\text { Review }\end{array}$ & Daily News & $\begin{array}{l}\text { Stockbrokers are pushing for a review of laws that ban local investors to sell } \\
\text { shares to foreigners from a company, with } 60 \text { per cent overseas ownership } \\
\text { (Elinaza, 2012). }\end{array}$ \\
\hline $\begin{array}{l}\text { Dar es Salaam Bourse Records } \\
\text { Low Trade On Flat Counters }\end{array}$ & & $\begin{array}{l}\text { Overall drop of market activities as most counters either remained flat or lost their } \\
\text { values during the specified week. Improvement of the activity levels was caused } \\
\text { by the sale of TATEPA (TTP) shares to foreign investors in a pre-arranged deal } \\
\text { (Elinaza, 2012). }\end{array}$ \\
\hline $\begin{array}{l}\text { Dividends Push Up Dar es } \\
\text { Salaam Bourse Trade }\end{array}$ & Daily News & $\begin{array}{l}\text { DSE trading activities were set to increase as the bourse enters into the season of } \\
\text { annual dividends. Traditionally, most DSE's investors tend to target dividends as } \\
\text { their main investment returns instead of capitalising by buying and selling when } \\
\text { share prices fluctuates (Elinaza, 2012). }\end{array}$ \\
\hline $\begin{array}{l}\text { Banks Shine At Dar es Salaam } \\
\text { Bourse }\end{array}$ & Daily News & $\begin{array}{l}\text { Listed Banks became the most liquid stocks in the trading sessions of the week } \\
\text { with NMB contributing about } 70.12 \text { per cent per cent of the total market turnover } \\
\text { (Mrindoko, 2012). }\end{array}$ \\
\hline Trading to Pick Up On DSE As & Daily News & Trading on the DSE was expected to pick up as yields from fixed income \\
\hline
\end{tabular}




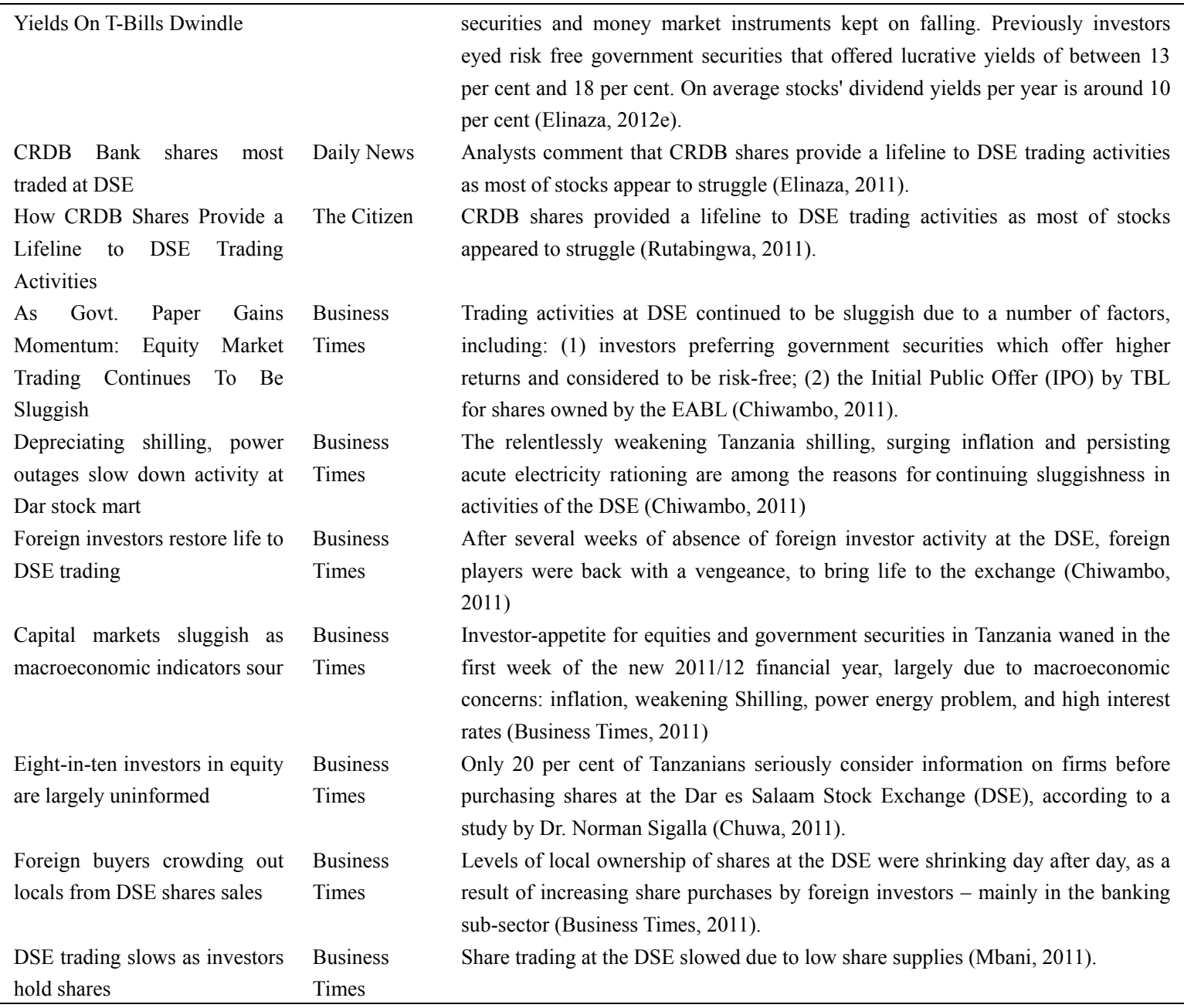

It follows that market efficiency, random walk, and predictability are related financial aspects, useful in explaining memory effects in security markets. Long memory means slow price discovery and market inefficiency, characterized with persistent prices and periodic cycles. Short memory is the contrary. This paper, therefore, analyzes these issues in the context of the DSE. The need to study the Tanzania stock market is substantiated with two main contributions. Firstly, there is a limited literature on infant stock markets, especially African markets. Several reasons are usually mentioned for lack of interest in studying infant African markets such as: lack of sufficient data, the smallness and newness of the markets, land lack of integration and visibility to external markets. However, these reasons are unjustifiable because knowledge on infant stock market is as important as knowledge in advanced markets: regardless of their context, size and proximity to other markets. This study, therefore, endeavors to narrow the existing wide knowledge gap on African stock markets. Secondly, the study contributes in providing empirical evidence on characteristic features of the DSE, thereby aiding investors and other stakeholders in making informed decisions. Overall, the study attempts to explain whether or not price discovery, one of the core functions of stock markets, can be achieved in infant markets like the DSE.

There are several financial forecasting approaches like Autoregressive Conditional Heteroskedasticity (ARCH-type) models (Engle, 1982; Bollerslev, 1986), Vector Error Correction Models (Johansen, 1988, 1991) and so on. In this study we apply simple tests for stock return distribution and memory effects. The aim is to use the dynamic features of the DSE stock index and the deterministic features of the market to explain the efficiency of the price discovery mechanism. Specifically, we analyze the distribution of the index in relation to serial correlation, heteroskedasticity and normality as well as measuring for unit root and random walk. Overall our results suggest that the price discovery mechanism at DSE is inefficient, alongside strong evidence of non-normality and stationarity. Moreover, the index appears to exhibit structural shifts, mainly associated with stock listings.

The remainder of the paper is organized as follows. Section 2 describes the modeling approach for memory 
effects in the price discovery mechanism, while section 3 describes the DSE stock index and data properties. Section 4 presents empirical results and discussions on memory effects, whereas section 5 provides an overall conclusion.

\section{Modeling Memory Effects in the Pricing Mechanism}

Consider a discrete time stochastic process as $P_{t}=\left(P_{1}, P_{2}, P_{3} \ldots P_{T}\right)$, where $P_{t}$ is the natural logarithm of either the stock price or return observed at trading days, and $T$ is the number of observations. This process can be modeled as an autoregressive process of order $p$ as:

$$
\begin{gathered}
P_{t}=c+\alpha_{1} P_{t-1}+\alpha_{2} P_{t-2} \ldots+\alpha_{p} P_{t-p}+\varepsilon_{t} \\
\varepsilon_{t} \backslash \Omega_{t-1} \approx N\left(0, \sigma^{2}\right)
\end{gathered}
$$

$\varepsilon_{t}$ is the random error term assumed to be normally distributed, with mean zero and constant variance $\sigma^{2}$, upon a previous set of information $\Omega_{\mathrm{t}-1.1}$. If the coefficient $\alpha$ is statistically significant, today's prices depend on yesterday's prices. This stochastic process can be used to test for memory, by using a simple unit root test. For a first order autoregressive process $(p=1)$, there is unit root when $\alpha_{l}=1$. For a higher orders of $p$, the process has a unit root when $\Sigma\left(\alpha_{1}+\alpha_{2}+\alpha_{p}\right)=1$. Unit root means the time series is nonstationary and the moment of the stochastic process depends on time $(t)$.

Moreover, it is the random error term that explains whether or not the current prices reflect previous set of information. Thus, residual serial correlation can provide a further measure of the relationship between current prices and information. We consider the popular Lagrange multiplier (LM) test for large samples (see Godfrey, 1988). LM tests the null hypothesis that there is no serial correlation in residuals up to a specified lag order $(p)$. This is the advantage of LM over other tests like Durbin Watson, which are unable to capture serial correlation in higher orders. The LM test is based on auxiliary regression because $\varepsilon_{t}$ is unobservable. From equation (1) an auxiliary error term $(e)$ can be expressed as,

$$
e_{t}=\gamma P_{t-1}+\left(\sum_{s=1}^{p} \phi_{s} e_{t-s}\right)+v_{t}
$$

Further, we can test for heteroskedasticity in the residuals, using ARCH-LM test (Engle, 1982). This test is based on the null hypothesis that there is no ARCH up to lag order $q$ in residuals $(e)$. It is based on regressing the squared residuals on a constant and lagged squared residuals, as follows:

$$
e_{t}^{2}=\alpha_{0}+\left(\sum_{s=1}^{q} \alpha_{s} e_{t-s}^{2}\right)+v_{t}
$$

In both tests (LM serial correlation and ARCH-LM), the respective null hypotheses are rejected by the statistical significance of the $F$-statistics on an OLS regression, with observations $(T)$ and numbers of dependent variables (k). Thus,

$$
\begin{gathered}
F=\frac{R^{2} /(k-1)}{\left(1-R^{2}\right) /(T-k)} \\
\text { where, } R^{2}=1-\frac{\widehat{\mathcal{E}^{\prime} \mathcal{\varepsilon}}}{\left(P-P^{\prime}(P-P)\right.} ; \quad \widehat{P}=\sum_{t=1}^{T} P_{t} / T \\
\text { and } \widehat{\mathcal{E}^{\prime}} \widehat{\varepsilon}=\sum_{t=1}^{T}\left(P_{t}-\alpha P_{t-1}\right)^{2} ; \widehat{\varepsilon}=P_{t}-\alpha P_{t-1}
\end{gathered}
$$

To test random walk, suppose the time series $P_{t}$, satisfies,

$$
\Delta P_{t}=\mu+\varepsilon_{t}
$$

where $\mu$ is an arbitrary drift parameter. The key properties of a random walk to be tested are from expectations $(E)$, such that $E\left(\varepsilon_{t}\right)=0$ for all $t$ and $E\left(\varepsilon_{t} \varepsilon_{t-j}\right)=0$ for any positive $j$. From Lo and MacKinlay (1988), random walk tests can be performed using two test statistics under different sets of null hypothesis assumption about the random error $\left(\varepsilon_{t}\right)$. The first test is referred to as homoscedasticity random walk, in which $\varepsilon_{t}$ is assumed to be normally distributed (Gaussian) with variance $\sigma^{2}$. The second set is called heteroskedastic random walk, which relaxes the common normality assumption and provide for fairly general forms of conditional heteroskedasticity and dependence.

The estimators for the mean and first difference and scaled variance of the $q$-th difference can be defined as, 


$$
\begin{gathered}
\widehat{\mu}=\frac{1}{T} \sum_{t=1}^{T}\left(P_{t}-P_{t-1}\right) \\
\widehat{\sigma^{2}}(q)=\frac{1}{T q} \sum_{t=1}^{T}\left(P_{t}-P_{t-1}-q \widehat{\mu}\right)^{2}
\end{gathered}
$$

In order to adjust for bias, $T$ in equation (9) and (10) can be replaced with $(T-q+1)$ or $(T-q+1)(1-q / T)$ for a non-drift and with-drift cases, respectively. The corresponding variance ratio $(V R)$ is defined as,

$$
\operatorname{VR}(q)=\widehat{\sigma}^{2}(q) / \widehat{\sigma^{2}}(1)
$$

The test statistic $(\mathrm{z})$ for variance ratio is asymptotically $N(0,1)$ for appropriate choice of estimator $\left[\widehat{s^{2}}(q)\right]$, such that,

$$
z(q)=(V R(q)-1)\left[\widehat{S}^{2}(q)\right]^{-1 / 2} ; s=\sqrt{\frac{\widehat{\mathcal{E}^{\prime} \hat{\varepsilon}}}{(T-k)}}=\text { Standard error }
$$

Thus, the estimator for the normality assumption is,

$$
\widehat{s}^{2}(q)=\frac{2(2 q-1)(q-1)}{3 q T}
$$

While the relaxation of normality leads into a kernel estimator,

$$
\begin{gathered}
\widehat{s^{2}}(q)=\sum_{j=1}^{q-1}\left(\frac{2(q-j)}{q}\right)^{2} \widehat{\delta_{j}} \\
\text { where, } \widehat{\delta_{j}}=\left\{\sum_{t=j+1}^{T}\left(p_{t-j}-\widehat{\mu}\right)^{2}\left(p_{t}-\widehat{\mu}\right)^{2}\right\} /\left\{\sum_{t=j+1}^{T}\left(p_{t-j}-\widehat{\mu}\right)^{2}\right\}^{2}
\end{gathered}
$$

Following Chow and Denning (1993), joint variance ratio tests are enabled by restricting $p>1$. Further details on empirical application are available in Fong, Koh and Ouliaris (1997). Moreover, Kim (2006) offers an improved approach (wild bootstrap) for testing both individual variance ratio and joint variance ratio.

\section{Data and the DSE Stock Index Structure}

\subsection{Data and Descriptive Statistics}

The DSE categorizes its indices into different classes namely: All Share Index (ASI), Tanzania Share Index (TSI), Foreign Share Index (FSI), Industrial and Allied Share Index (ISI), Banking and Insurance Share Index (BSI) and Commercial Services Share Index (CSI).

Table 2. DSE listed stocks

\begin{tabular}{lllll}
\hline SN & Stocks & Base & Industry & Date Listed $^{\#}$ \\
\hline 1 & Tol Gases Limited (TOL) & Tanzania & Energy & $04 / 15 / 1998$ \\
2 & Tanzania Breweries Limited (TBL) & Tanzania & Brewers & $09 / 09 / 1998$ \\
3 & Tanzania Tea Parkers Limited (TATEPA) & Tanzania & Beverage & $12 / 191999$ \\
4 & Tanzania Cigarette Company Limited (TCC) & Tanzania & Cigarette & $11 / 16 / 2000$ \\
5 & Tanga Cement Company Limited (SIMBA) & Tanzania & Cement & $09 / 26 / 2002$ \\
6 & Swissport Tanzania Limited (Swiss) & Tanzania & Aviation & $06 / 03 / 2003$ \\
7 & Kenya Airways Limited (KA) & Kenya & Aviation & $10 / 01 / 2004$ \\
8 & East African Breweries Limited (EABL) & Kenya & Brewers & $06 / 29 / 2005$ \\
9 & Tanzania Portland Cement Co. Limited (TWIGA) & Tanzania & Cement & $09 / 26 / 2006$ \\
10 & Jubilee Holdings Limited (JHL) & Tanzania & Insurance & $12 / 20 / 2006$ \\
11 & Dar es Salaam Community Bank (DCB) & Tanzania & Banking & $09 / 16 / 2008$ \\
12 & National Microfinance Bank (NMB) & Tanzania & Banking & $11 / 06 / 2008$ \\
13 & Kenya Commercial Bank Limited (KCB) & Kenya & Banking & $12 / 17 / 2008$ \\
14 & CRDB Bank Public Limited (CRDB) & Tanzania & Banking & $06 / 17 / 2009$ \\
15 & National Media Group Limited (NMG) & Kenya & Media & $02 / 21 / 2011$ \\
16 & African Barrick Gold Plc (ABG) & United Kingdom & Mining & $12 / 07 / 2011$ \\
17 & Precision Air Services Plc (PAL) & Tanzania & Aviation & $12 / 21 / 2011$ \\
\hline
\end{tabular}

Note. ${ }^{\#}$ In the entire paper, dates follow the sequence MM/DD/YYYY. That is Month/Date/Year. 
This study uses the ASI in order to capture information about the entire market, comprised of seventeen listed stocks (see Table 2). The ASI data was obtained from DSE (upon request) spanning from December $1^{\text {st }} 2006$ to June $13^{\text {th }} 2011$, covering 1125 observations of trading days. Stock price indices at DSE are reported in Tanzanian Shillings (TZS) per share on a particular trading day. For analysis purposes, we transform the TZS series it into natural logs, in which the first log difference defines stock index returns.

Table 3. Descriptive statistics and normality

\begin{tabular}{lllllll}
\hline & & Mean & Std. Deviation & Skewness & Kurtosis & Jarque-Bera \\
\hline Whole & TZS (level) & 1129.5090 & 86.3777 & -0.2510 & 1.4543 & $123.8013(0.000)$ \\
& Log (level) & 7.0266 & 0.0775 & -0.2953 & 1.4618 & $127.2535(0.000)$ \\
& Log (difference) & 0.0002 & 0.0048 & 18.5458 & 478.0567 & $106.3337(0.000)$ \\
Sub-sample 1 & TZS (level) & 1125.1590 & 87.3257 & -0.1836 & 1.3748 & $55.6412(0.000)$ \\
& Log (level) & 7.0212 & 0.0778 & -0.1346 & 1.3906 & $53.3631(0.000)$ \\
& Log (difference) & 0.00005 & 0.0023 & -0.9761 & 52.9746 & $503.6600(0.000)$ \\
Sub-sample 2 & TZS (level) & 1134.427 & 86.9591 & -0.3677 & 1.5061 & $74.3960(0.000)$ \\
& Log (level) & 7.0266 & 0.0761 & -0.2787 & 1.4607 & $71.9181(0.000)$ \\
& Log (difference) & 0.0002 & 0.0030 & 1.8086 & 36.9110 & $311.5900(0.000)$ \\
\hline
\end{tabular}

Note. Numbers in parentheses are p-values.

Table 3 presents descriptive statistics and normality distribution of the index. From the Jarque-Bera test, there is strong evidence of non-normality in the index series. Regarding skeweness, the index (levels) appears to be left-skewed, while the returns are right-skewed (except in sub-sample 1). Left-skeweness implies a greater chance of extremely negative outcomes as well as asymmetry, whereas the right-skeweness in returns implies minimal losses to investors during the covered period. Kurtosis for the index appears to be normal (below the accepted level of 3). However, returns exhibit extremely high kurtosis, suggesting the moments of very low and very high returns than expected. These distribution features are clearly envisaged in Figures 1 to 3.

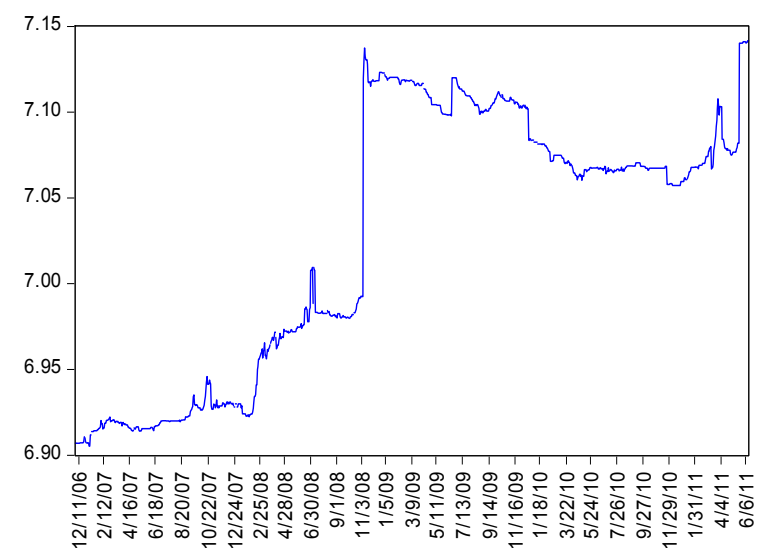

(i) Log Level

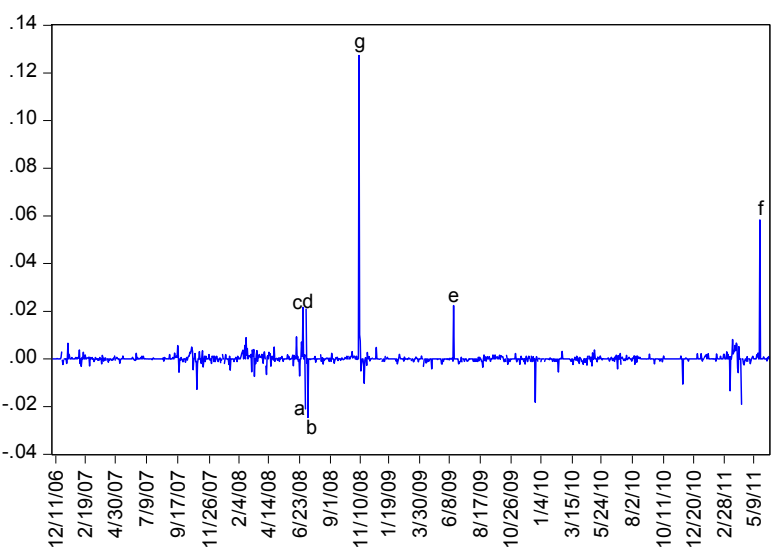

(ii) Returns

Figure 1. Index structure (December 1st 2006 to June 13th 2011) 


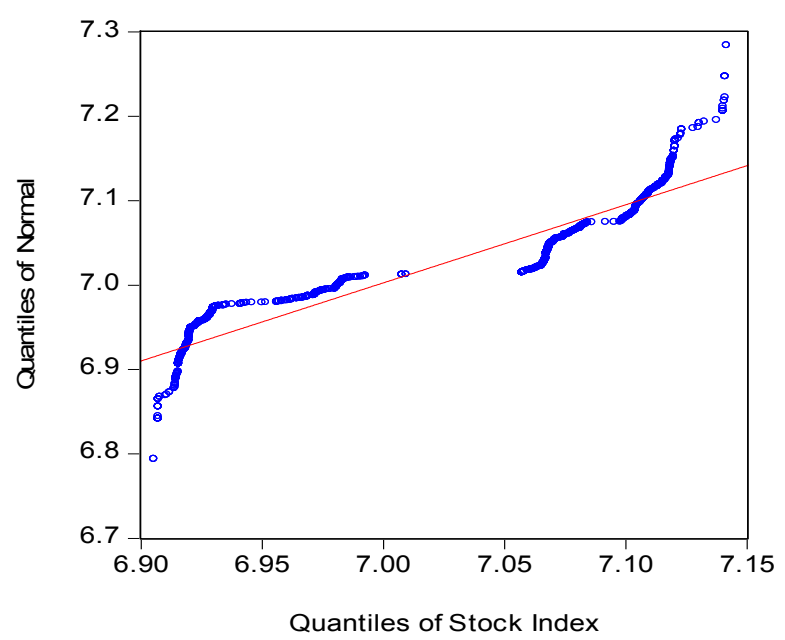

(i) Log level

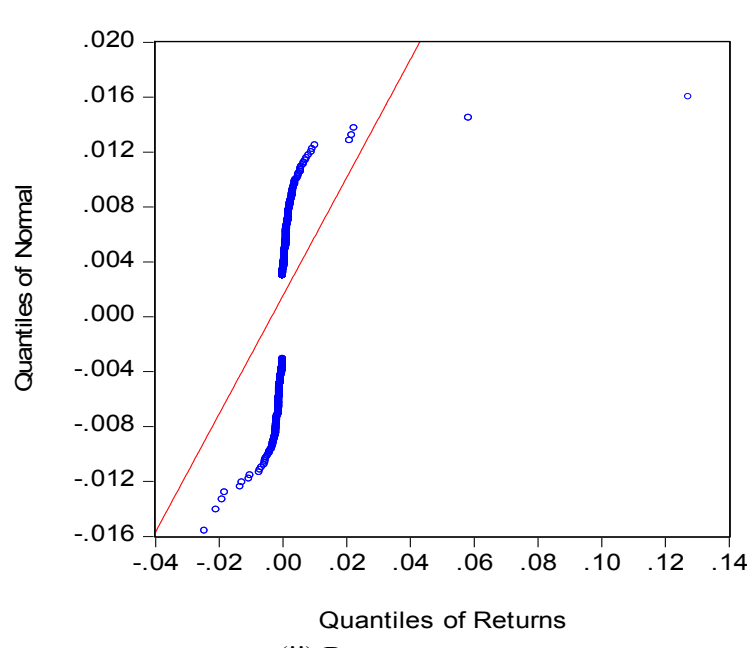

(ii) Returns

Figure 2. Quantiles of normal

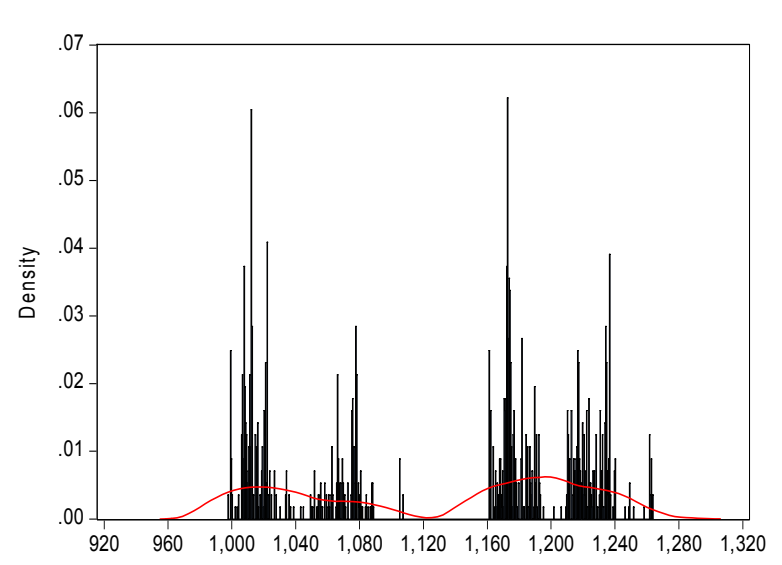

(i) Log level

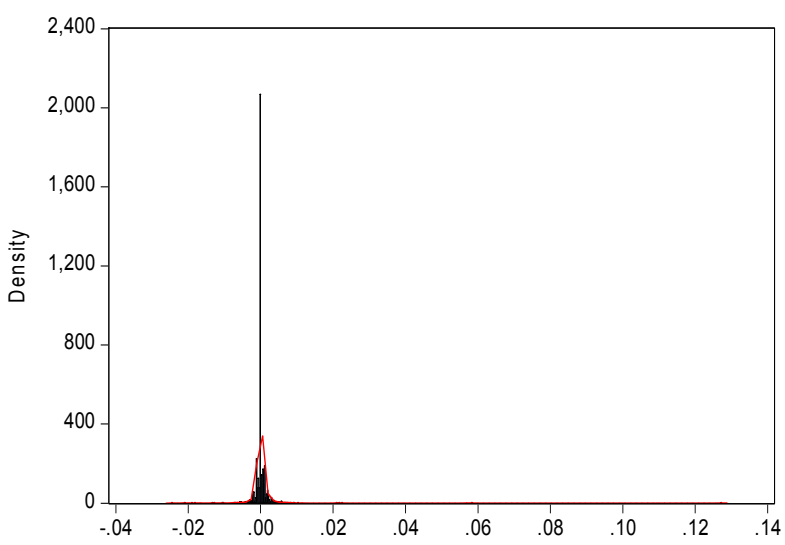

(ii) Returns

Figure 3. Index distribution density

Figure 1 depicts the series structure of the ASI (log levels) and returns (log differences). There is a clear evidence of a structural shift in November $6^{\text {th }}$ 2008. In Figure 1(ii), the index returns are characterized by remarkable outliers (abnormal or unexpected returns), whose points are marked a to g. These points correspond to certain market events identified in Table 4 (together with cross tabulation): points a (July $4^{\text {th }} 2008$ ) and b (July $\left.11^{\text {th }} 2008\right)$ coincides with activities to delist the National Investment Company (NICOL) after a one-month suspension in June 2008. NICOL was delisted effectively from July 6th 2008 due to failure to comply with financial statement disclosure requirements. July 4th and 11th 2008 were Fridays before and after the effective delisting, respectively. The outliers in both points indicate loss of returns of almost 2 percent, on average. Our efforts to identify any event on point $c$ (June $30^{\text {th }} 2008$ ) and point d (July $8^{\text {th }} 2008$ ) were unsuccessful. Point e (June $17^{\text {th }} 2009$ ) is the CDRB listing date in which the market return was about 2 percent, while point $\mathrm{f}$ (May $23^{\text {rd }} 2011$ ) corresponds to CRDB's dividend activities. On this date point, the market return was about 6 percent, which was just a day before trading of shares cum-dividend at the bank. During the corresponding period CRDB made key announcements about dividend payment as follows: Announcement of dividend payment (May $5^{\text {th }}$ 2011), trading of shares cum-dividend (May $5^{\text {th }} 2011$ to May 24 $4^{\text {th }} 2011$ ), and trading of shares ex-dividend (May $25^{\text {th }} 2011$ onwards), among other announcements. Date point $g$ coincides with NMB listing date, leading to a return of about 13 percent.

Figure 2 provides a better view of distribution in the index and returns, using quantiles of normal. Clearly, the quantiles of normal do not lie in the diagonal straight lines, suggesting that mainly positive shocks drive the index from normality, while both positive and negative shocks equally drive the returns from normality. Moreover, the quantiles appear to be separated into two parts, thereby providing a further evidence of a structural 
break. The histograms and distribution density in Figure 3 confirm skeweness in the index. From Table 4, we also see that 75 percent of the returns ( 843 observations) are between 0 and 2 percent, while about 24 percent ( 274 observations) are losses of between 0 and 2 percent. The overall interpretation is that investors are not expected to have any gains or losses of more than 2 percent. Any gain or loss of more than 2 percent is regarded as abnormal (unexpected). Indeed, these abnormal earnings or losses appear to be very rare (and as evidenced in the right-skeweness and excess kurtosis).

Table 4. Tabulation of index returns

\begin{tabular}{lllll}
\hline Value & Count & Percent & Outlier Dates & Outlier Values \\
\hline-0.04 to -0.02 & 2 & 0.18 & ${ }^{\mathrm{a}} 07 / 04 / 2008,{ }^{\mathrm{b}} 07 / 11 / 2008$ & $-0.021,-0.025$ \\
-0.02 to 0 & 274 & 24.38 & & \\
0 to 0.02 & 843 & 75.00 & & \\
0.02 to 0.04 & 3 & 0.27 & ${ }^{\mathrm{c}} 06 / 30 / 2008,{ }^{\mathrm{d}} 07 / 08 / 2008,{ }^{\mathrm{e}} 06 / 17 / 2009$ & $0.021,0.021,0.022$ \\
0.04 to 0.06 & 1 & 0.09 & ${ }^{\mathrm{f}} 05 / 23 / 2011$ & 0.058 \\
0.12 to 0.14 & 1 & 0.09 & ${ }^{\mathrm{g}} 11 / 06 / 2008$ & 0.127 \\
\hline
\end{tabular}

Note. ${ }^{\mathrm{a}, \mathrm{b}}$ The period from July $4^{\text {th }}$ to $11^{\text {th }}$ coincide with activities to delist the National Investment Company (NICOL).

${ }^{\mathrm{c}, \mathrm{d}}$ Unable to define corresponding events.

e,f The periods coincide with CRDB listing and dividend announcements, respectively.

${ }^{\mathrm{g}}$ The periods coincide with NMB stock listing dates.

This small market return is probably a reason for investors' more preference in dividend income than stock trading income (see Table 1). On average, DSE investors expect a dividend yield of about 10 percent annually. Comparing with alternative investment in government securities, the overall returns from stock portfolio investments (from both share trading and dividend) are lower. Government securities provide yields of between 13 and 18 percent on average. This may explain the tendency of inactive trading at the DSE floor in most times as investors are attracted by more lucrative earnings in Treasury bond portfolios.

\subsection{Structural Shift}

It is important to confirm the vivid structural shift, which is evident in November $6^{\text {th }} 2008$, and test for any possibility of other breakpoints in the DSE index. Since, it is not easy to identify most of the breakpoints with an eyeball of the graphs, we apply a combination of methods developed by Chow (1960), Quandt (1960), Andrews (1993). The Chow approach is based on parameter equality of two sub-samples of the estimated data series. Its limitation is that the breakpoint to be tested must be known in prior. In our case, we assume the known breakpoint to be November $6^{\text {th }} 2008$, which becomes a point for separating the data series into two sub-samples. Sub-sample 1 is truncated to November $5^{\text {th }} 2008$, while sub-sample 2 spans from November $6^{\text {th }} 2008$ onwards. The Quandt-Andrews approach is more general because it does not require any prior knowledge about breakpoints. For further details about the applications and limitations of these tests refer to Hansen (2001).
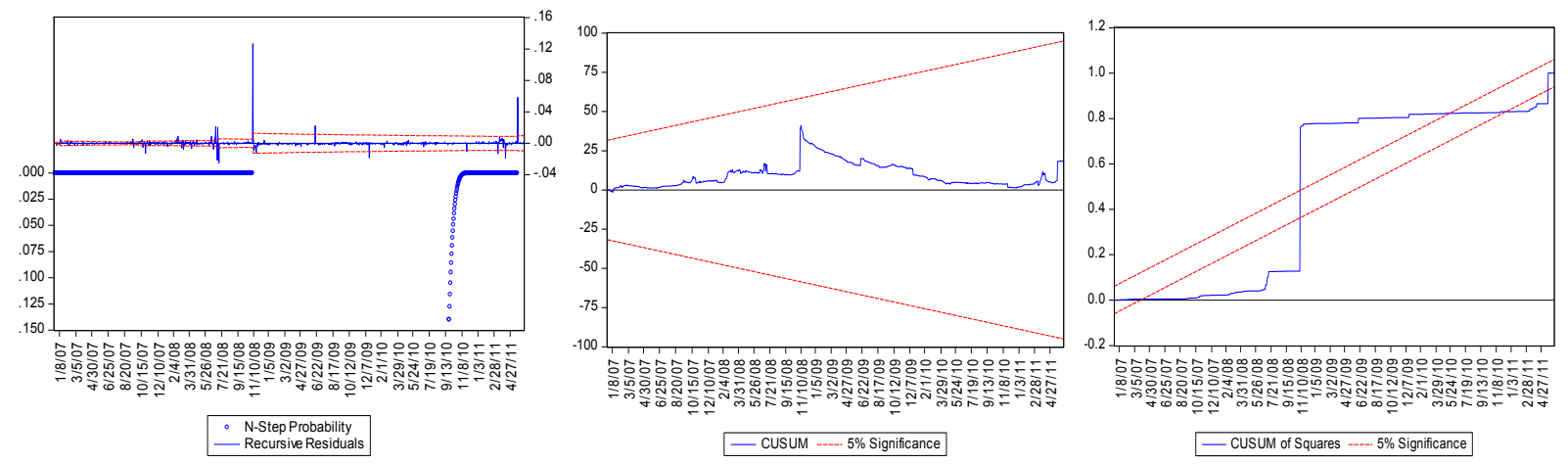

Figure 4. Parameter stability and breakpoint identification: whole sample 

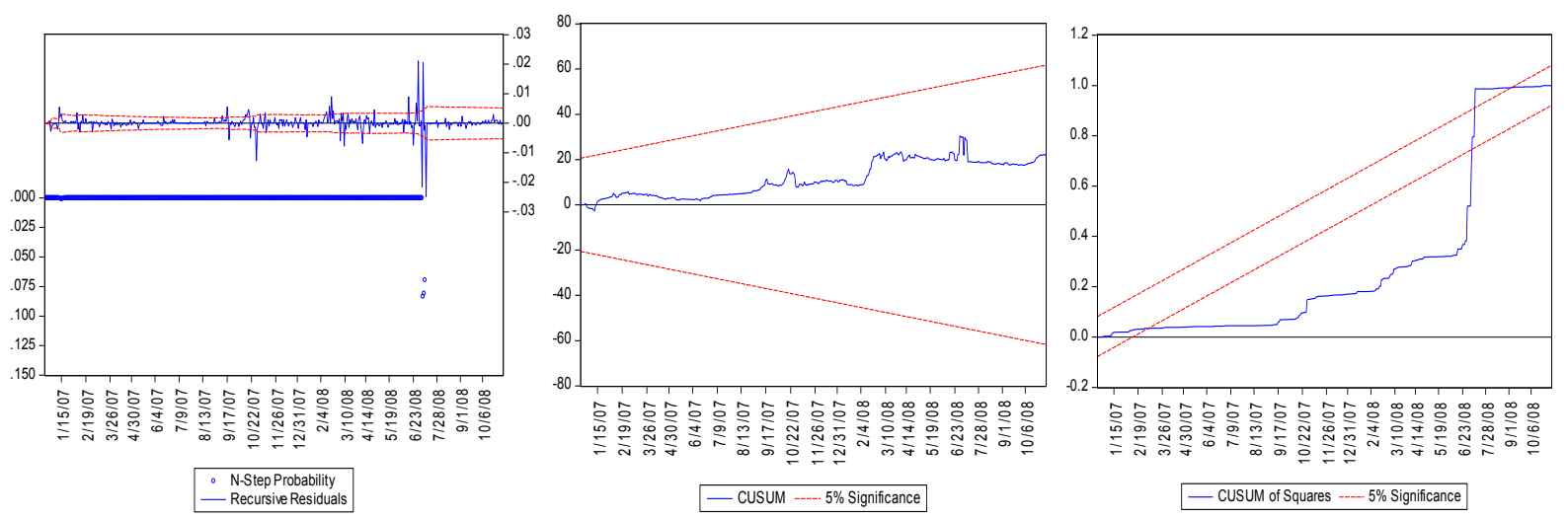

Figure 5. Parameter stability and breakpoint identification: sub-sample 1
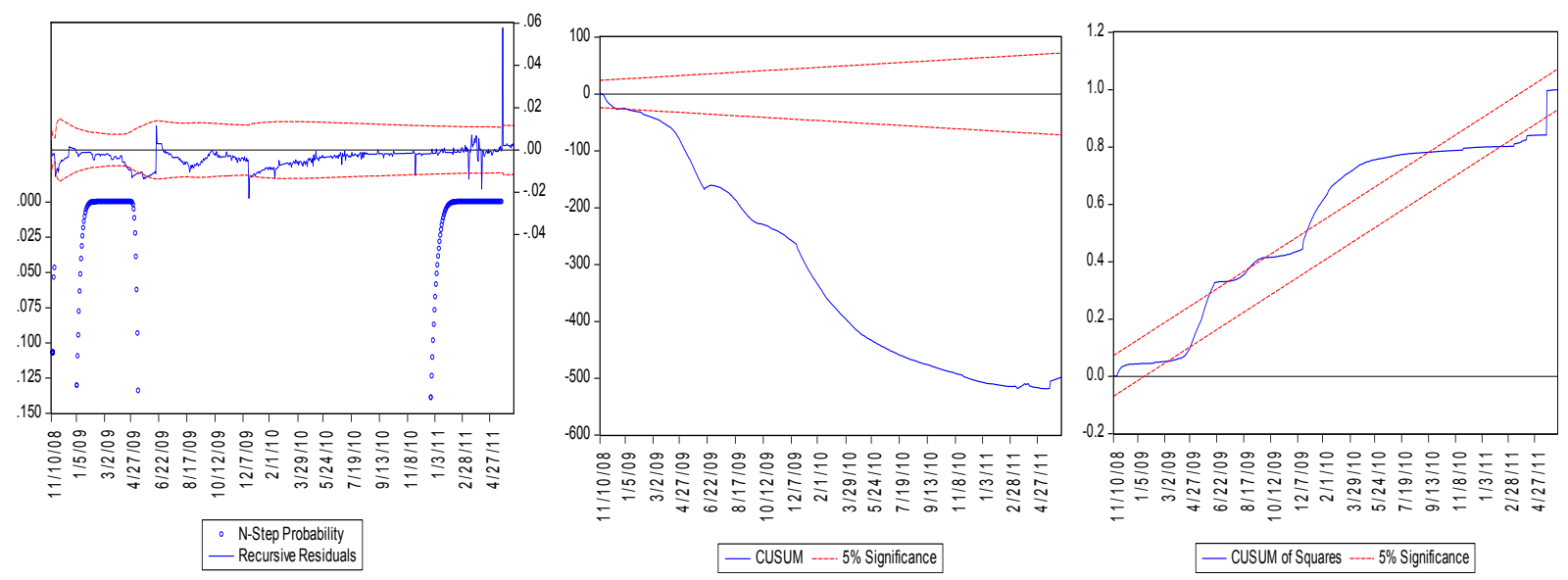

Figure 6. Parameter stability and breakpoint identification: sub-sample 2

The first step for running breakpoint tests is to estimate an OLS autoregressive (AR) regression in the series for each sample. The second step is to conduct stability tests on the estimated residuals for identifying breakpoint using corroborative graphs for residual tests (see Figure 4 to 6). These graphs not only help to check parameter stability, but also provide a general view on any possible breakpoint that could be assumed as known breaks for Chow tests. The first graph (left side) shows a joint plot of recursive residuals and N-step probabilities. The recursive residuals are based on a one-step ahead forecast error resulting from a prediction process of least square estimations of subsets of sample data. If the recursive residuals are independently and normally distributed with zero mean and constant variance, the estimated parameters are assumed to be stable. The resultant graphs show the recursive residuals about the zero line, and plus and minus two standard errors at each point. Residuals outside the standard error bands would suggest instability in the parameters of the equation and a possibility of a breakpoint. The N-step probabilities show the statistical significance of the recursive residuals from a sequence of Chow Forecast tests using recursive calculations. Constant and statistically significant probabilities would suggest a stable period during the sample, while a break and insignificant probabilities suggest a possibility of structural shifts.

The other two graphs show Cumulative Sum of the recursive residuals (CUSUM) and the Cumulative Sum of Squares (CUSUM-SQ) following Brown, Durbin, and Evans (1975). The CUSUM (middle) are plotted together with the 5 percent critical lines. The CUSUM-SQ test is based on a test statistic (S), positing a constant parameter around expected values. The significance of the departure of $\mathrm{S}$ from its expected value is assessed by reference to a pair of parallel straight lines around the expected value. In the CUSUM-SQ plots (right side), $\mathrm{S}$ is plotted against time and the pair of 5 percent critical lines. In both CUSUM and CUSUM-SQ, a movement outside the critical lines suggests parameter or variance instability, and a sharp departure from the zero horizontal axes would suggest a possible breakpoint.

Finally, we apply the Chow and Quandt-Andrews approaches. For Chow tests, we test the entire sample, taking November $6^{\text {th }} 2008$ as known shift points. For sub-samples, based on parameter stability plots we assume 
breakpoints on June $26^{\text {th }} 2008$ and July $11^{\text {th }} 2008$ for sub-sample 1 , while June $17^{\text {th }} 2009$ (CRDB listing) is tested for sub-sample 2. For the Quandt-Andrews approach we acknowledge the fact that structural shift tests tend to be sensitive to sample sizes or number of observations (see for example, Inclan \& Tiao, 1994; Smith, 2008). Therefore, we do not only test the whole sample, but also each sub-sample is tested separately for any unknown breakpoints.

Table 5. Structural shift tests

\begin{tabular}{llcc}
\hline & Statistic & $\begin{array}{c}\text { Chow Test } \\
\text { (Known Shift) }\end{array}$ & $\begin{array}{c}\text { Quandt-Andrews Test } \\
\text { (Unknown Shift) }\end{array}$ \\
\hline Whole Sample & F-statistics & ${ }^{\mathrm{a}} 12.6130^{* * *}$ & ${ }^{\mathrm{a}} 13.0204^{* * *}$ \\
& & $(0.000)$ & $(0.000)$ \\
& Log likelihood ratio & ${ }^{\mathrm{a}} 25.0351^{* * *}$ & \\
& & $(0.000)$ & \\
Wald statistic & ${ }^{\mathrm{a}} 25.2259^{* * *}$ & ${ }^{\mathrm{a}} 26.0409^{* * *}$ \\
& & $(0.000)$ & $(0.000)$ \\
& F-statistics & ${ }^{\mathrm{b}} 42.4312^{* * *}$ & ${ }^{\mathrm{c}} 29.2127^{* * *}$ \\
& & $(0.000)$ & $(0.000)$ \\
& Log likelihood ratio & ${ }^{\mathrm{b}} 146.9108^{* * *}$ & \\
& & $(0.000)$ & \\
Wub-sample 1 & ${ }^{\mathrm{b}} 169.7249^{* * *}$ & ${ }^{\mathrm{c}} 58.4253^{* * *}$ \\
& & $(0.000)$ & $(0.000)$ \\
& F-statistics & ${ }^{\mathrm{d}} 233.3575^{* * *}$ & ${ }^{\mathrm{c}} 676.6985^{* * *}$ \\
& & $(0.000)$ & $(0.000)$ \\
& Log likelihood ratio & ${ }^{\mathrm{d}} 352.7080^{* * *}$ & \\
& & $(0.000)$ & \\
& Wald statistic & ${ }^{\mathrm{d}} 466.7150^{* * *}$ & ${ }^{\mathrm{e}} 1353.397^{* * * *}$ \\
& & $(0.000)$ & $(0.000)$ \\
\hline
\end{tabular}

Note. In Quandt-Andrews, shift points are identified with maximum LR F-statistic and maximum Wald F-statistic, whose probabilities are calculated using Hansen's (1997) approach.

Breakpoints: ${ }^{\mathrm{a}} 6^{\text {th }}$ November $2008,{ }^{\mathrm{b}} 26^{\text {th }}$ June 2008 and $11^{\text {th }}$ July $2008,{ }^{\mathrm{c}} 4^{\text {th }}$ June $2008,{ }^{\mathrm{d}} 17^{\text {th }}$ June $2009,{ }^{\mathrm{e}} 1^{\text {st }}$ April 2009.

*** Statistically significant at $1 \%$ level. Numbers in parentheses are p-values of the respective test statistics.

Technically, both approaches use two test statistics: the F-statistic, which is based on the comparison of the restricted and unrestricted sum of squared residuals from the estimated OLS equations; and the Wald statistic. In the Chow approach, the Log Likelihood Ratio statistic, which is based on the comparison of the restricted and unrestricted maximum of the (Gaussian) log likelihood function, is used in addition. The presence of breakpoints is suggested by a statistical significance of each of the test statistics. Our results for structural breakpoints are reported in Table 5. The tests indicate a high statistical significance of 1 percent level. Overall, the identified shift points are consistent with our identifications from stability tests. Some of them coincide with stock listing dates for NMB and CRDB, thereby providing a view of the validity of the tests.

\section{Estimated Results}

Our baseline estimations are based on a simple autoregressive process with OLS. Due to structural breaks identified above, all processes are estimated for three samples (whole, sub-sample 1 and sub-sample 2) in order to enable inference of the impact of the main structural break of November $6^{\text {th }} 2008$.

Firstly, we run a set of autoregressive processes on equation (1) in order to determine unit root properties. For each sample, the order of the best stochastic process is determined by applying information four filtering technics: Log Likelihood (LL), Akaike Information Criteria (AIC), Schwartz Information Criteria (SIC), and Hannan-Quinn Information Criteria (HQIC). The best autoregressive process is selected for processes with either the largest values of L and smallest values of AIC, SIC and HQIC. Where LL provided contradicting outcomes, our order process is based on AIC, SIC and HQIC. The selection process starts with estimating four processes for each sample, with orders 1 to 4 . The information filters for the corresponding estimates are reported in Table 6 . Hence, our final selections were order 1 for whole and sub-sample 2, and order 3 for sub-sample 1. 
Table 6. Selection criteria for order processes

\begin{tabular}{llllll}
\hline & & Order 1 & Order 2 & Order 3 & Order 4 \\
\hline Whole & LL & $\mathbf{4 4 1 3 . 3 3 2}$ & 4410.472 & 4407.252 & 4402.828 \\
& AIC & $-\mathbf{7 . 8 5 8 1}$ & $\mathbf{- 7 . 8 5 8 2}$ & -7.8577 & -7.8550 \\
& SIC & $\mathbf{- 7 . 8 5 3 6}$ & -7.8493 & -7.8442 & -7.8371 \\
Sub-sample 1 & HQIC & $\mathbf{- 7 . 8 5 6 4}$ & $-7-8549$ & -7.8534 & -7.8483 \\
& LL & $\mathbf{2 1 7 4 . 1 7 0}$ & 2172.216 & 2173.883 & 2168.855 \\
& AIC & -9.0738 & -9.0804 & $\mathbf{- 9 . 1 0 2 2}$ & -9.0960 \\
& SIC & -9.0651 & -9.0630 & $\mathbf{- 9 . 0 7 6 0}$ & -9.0610 \\
Sub-sample 2 2 & HQIC & -9.0704 & -9.0735 & $\mathbf{- 9 . 0 9 1 9}$ & -9.0822 \\
& LL & 2396.854 & 2397.355 & 2397.565 & $\mathbf{2 3 9 7 . 5 6 6}$ \\
& AIC & $\mathbf{- 7 . 4 4 0 5}$ & -7.4390 & -7.4365 & -7.4334 \\
& SIC & $\mathbf{- 7 . 4 3 3 6}$ & -7.4251 & -7.4157 & -7.4057 \\
& HQIC & $\mathbf{- 7 . 4 3 7 8}$ & -7.4336 & -7.4285 & -7.4227 \\
\hline
\end{tabular}

Note. The bolded numbers are the most preferable lag orders in different samples.

Table 7. OLS autoregressive estimates

\begin{tabular}{llllll}
\hline & & $\alpha 1$ & $\alpha 2$ & $\alpha 3$ & $\mathrm{R} 2$ \\
\hline Whole & Log level & $1.0000^{* * *}$ & & & 0.9962 \\
& & & & \\
& Returns & $0.000)$ & & & -0.0003 \\
& & $(0.173)$ & & & \\
Sub-sample 1 & Log level & $0.8790^{* * *}$ & $0.2288^{* * *}$ & $-0.1078^{* *}$ & 0.9919 \\
& & $(0.000)$ & $(0.000)$ & $(0.019)$ & \\
& Returns & $-0.0967^{* *}$ & $0.0940^{* *}$ & $-0.1665^{* * *}$ & 0.0521 \\
& & $(0.033)$ & $(0.039)$ & $(0.000)$ & \\
Sub-sample 2 & Log level & $1.0000^{* * *}$ & & & 0.9351 \\
& & $(0.000)$ & & & \\
& \multirow{2}{*}{ Returns } & $0.0658^{*}$ & & & 0.0028 \\
& & $(0.095)$ & & & \\
\hline
\end{tabular}

Note. $* * * * *, *$ Statistically significant at $1 \%, 5 \%$, and $10 \%$ level, respectively. Numbers in parentheses are F-statistics.

The results for the estimated stochastic autoregressive processes are reported in Table 7. For the index (Log levels), $\alpha_{1}=1$ for the whole and sub-sample 2, while $\sum\left(\alpha_{1}+\alpha_{2}+\alpha_{3}\right)=1$ for sub-sample 1 . The coefficients are statistically significant at 1 percent, suggesting that the current stock prices fully depend on previous prices, indicating long memory effects. Moreover, from the $\mathrm{R}^{2}$, more than 90 percent of the current prices are explained by previous prices. This effect disappears in stock returns, in which almost none of the current returns are explained by previous returns.

Table 8. Unit root tests

\begin{tabular}{llllll}
\hline & & \multicolumn{2}{c}{ With Constant } & \multicolumn{2}{c}{ With Constant + Trend } \\
\cline { 3 - 6 } & & $\log$ & $\Delta \log$ & $\log$ & $\Delta \log$ \\
\hline \multirow{2}{*}{ Whole } & Augmented Dickey Fuller (ADF) & -1.069 & $-32.206 * * *$ & -1.743 & $-32.191^{* * *}$ \\
& Phillips-Perron (PP) & -1.115 & $-32.226 * * *$ & -1.836 & $-32.211^{* * *}$ \\
\multirow{2}{*}{ Sub-sample 1 } & Augmented Dickey Fuller (ADF) & $-20.935^{* * *}$ & $-11.082^{* * *}$ & $-21.123 * * *$ & $-14.067 * * *$ \\
& Phillips-Perron (PP) & $-21.197 * * *$ & $-122.399^{* * *}$ & $-21.242^{* * * *}$ & $-122.182^{* * *}$ \\
\multirow{2}{*}{ Sub-sample 2 } & Augmented Dickey Fuller (ADF) & $-26.066^{* * *}$ & $-14.667 * * *$ & $-26.049 * * *$ & $-14.654^{* * *}$ \\
& Phillips-Perron (PP) & $-26.065^{* * *}$ & $-245.996^{* * * *}$ & $-26.048^{* * *}$ & $-246.122^{* * *}$ \\
\hline
\end{tabular}

Note. $* * *, * *, *$ Statistically significant at $1 \%, 5 \%$, and $10 \%$ level, respectively.

$\mathrm{ADF}$ and PP MacKinnon Critical values (with constant): $1 \%=-3.440 ; 5 \%=-2.870 ; 10 \%=-2.570$.

ADF and PP MacKinnon Critical values (with constant + trend): $1 \%=-3.966 ; 5 \%=-3.414 ; 10 \%=-3.129$. 
However, to corroborate the tests in Table 7, we proceed applying two advanced techniques for unit root test: Augmented Dickey Fuller (ADF) and Phillip-Perron (PP). For discussion and applications of these approaches refer to previous studies (e.g. Perron, 1986; Wang, 2003; Dionisio, Menezes, \& Mendes, 2007). The results are reported in Table 8. For the sub-samples, the tests suggest stationary in both index levels and returns. In the whole sample, the index levels are non-stationary while the returns are stationary. A possible explanation for non-stationarity in the whole sample is the presence of the structural break, especially the main break of November $6^{\text {th }}$ 2008. According to Perron (1989), structural breaks tend to effect unit root tests. From these corroborative tests, we can reasonably state that both index levels and returns are stationary.

Table 9. Variance ratio test for random walk

\begin{tabular}{lllllll}
\hline & Whole & & Sub-sample 1 & \multicolumn{3}{c}{ Sub-sample 2 } \\
\hline & Log Level & Returns & Log Level & Returns & Log Level & Returns \\
\hline Joint test & $\mathrm{a} 1.0523$ & $\mathrm{~b} 1.6045$ & $\mathrm{~b} 10.0577^{* * *}$ & $\mathrm{~b} 3.1547^{* * *}$ & $\mathrm{~b} 12.7517^{* * * *}$ & $\mathrm{a} 3.5859^{* * *}$ \\
& $(0.749)$ & $(0.369)$ & $(0.000)$ & $(0.006)$ & $(0.000)$ & $(0.001)$ \\
Period 2 & 1.0407 & $0.4937^{*}$ & $0.5023^{* * *}$ & $0.4668^{* * *}$ & $0.4527^{* * *}$ & $0.5591^{* * *}$ \\
& $(0.445)$ & $(0.109)$ & $(0.000)$ & $(0.002)$ & $(0.000)$ & $(0.001)$ \\
Period 4 & 1.0947 & 0.2612 & $0.2598^{* * *}$ & $0.2551^{* * *}$ & $0.2507^{* * *}$ & $0.2599^{* * *}$ \\
& $(0.293)$ & $(0.120)$ & $(0.000)$ & $(0.004)$ & $(0.000)$ & $(0.000)$ \\
Period 8 & 1.1194 & 0.1415 & $0.1200^{* * *}$ & $0.1354^{* * *}$ & $0.1135^{* * *}$ & $0.1282^{* * *}$ \\
& $(0.328)$ & $(0.124)$ & $(0.000)$ & $(0.005)$ & $(0.000)$ & $(0.001)$ \\
Period 16 & 1.0657 & 0.0616 & $0.0658^{* * *}$ & $0.0680^{* * *}$ & $0.0606^{* * *}$ & $0.0683^{* * *}$ \\
& $(0.675)$ & $(0.121)$ & $(0.000)$ & $(0.006)$ & $(0.000)$ & $(0.002)$ \\
\hline
\end{tabular}

Note. ${ }^{\mathrm{a}} \mathrm{Max}|\mathrm{z}|$ at period $4,{ }^{\mathrm{b}} \mathrm{Max}|\mathrm{z}|$ at period 2.

Numbers in parentheses are p-values.

$* * *, * *, *$ Statistically significant at $1 \%, 5 \%$, and $10 \%$ level, respectively.

Unit root does not necessarily imply random walk, although random walk is a common example of unit root. Therefore, we advance our tests for random walk using the approach proposed in Lo and MacKinlay $(1988,1989)$ as described in equations (8) to (15). The test results are displayed in Table 9. Additionally, in Figure 7, variance ratio statistics are plotted together with plus or minus two asymptotic standard error bands. The horizontal line at level 1 is a reference for the null hypothesis. The null of random walk is rejected in graphs whose null reference line lies outside the bands (sub-samples). The null hypothesis of random walk is strongly rejected on sub-samples at 1 percent level. However, on the whole sample, the hypothesis cannot be rejected. This might be due to the influence of the main structural shift. Hence, as a caution, we cannot rely on the whole sample to make any valid inference.

Finally, based on the estimated autoregressive process, we test for residual serial correlation and heteroskedasticity using LM and ARCH-LM as described in equations (3) to (7). The results are reported in Table 10. The null hypothesis of no serial correlation is rejected on sub-sample 1 since the test statistics are statistically significant. Note that, the rejection on index levels is strong with 1 percent level of significance, while in returns is only possible on lag order 2 and 4 (at 5 and 10 percent significance level). However, evidence of no serial correlation is strong on the whole and sub-sample 2, although it can be rejected at 1 and 5 percent significance levels. On the other hand, the null of no ARCH in residual is rejected too on sub-sample 1 with a 1 percent statistical significance. The general interpretation is that serial correlation is associated with heteroskedastic in the DSE index, and vice versa. Hence, for sub-sample 1, residuals autocorrelation is associated with a time-variant (non-constant) variance. It is the contrary on the whole and sub-sample 2 . This may implies that the main structural shift of November $6^{\text {th }} 2008$ might have changed the way the market respond to information, in which there was a higher dependence on previous price information prior to the structural shift than after. 


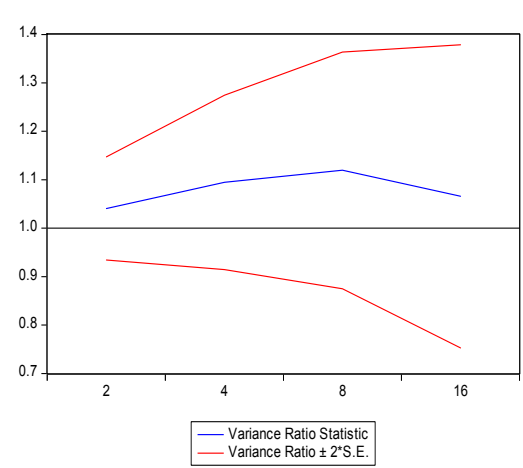

Whole (Log Level)

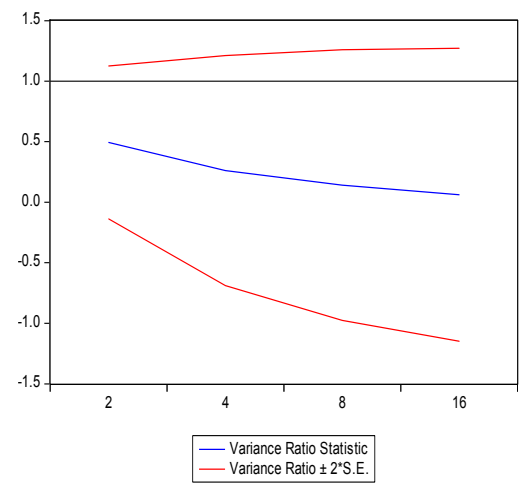

Whole (Returns)

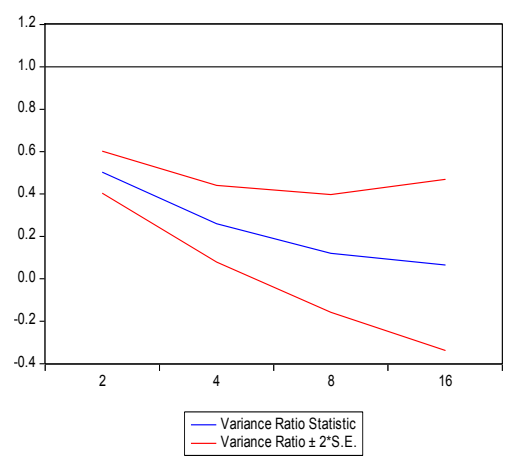

Sub-sample 1 (Log Level)

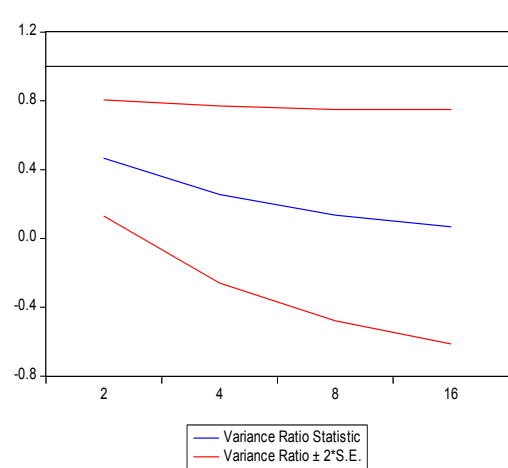

Sub-sample 1 (Returns)

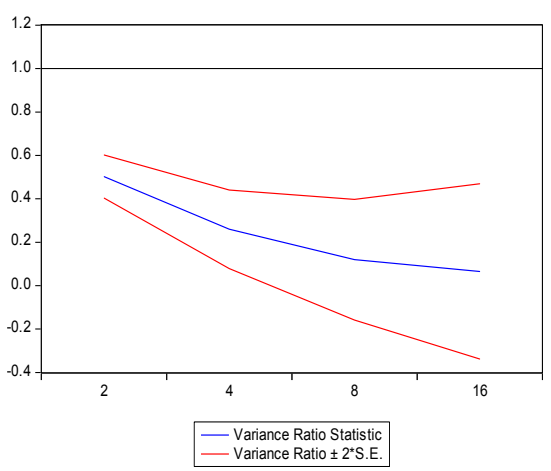

Sub-sample 2 (Log Level)

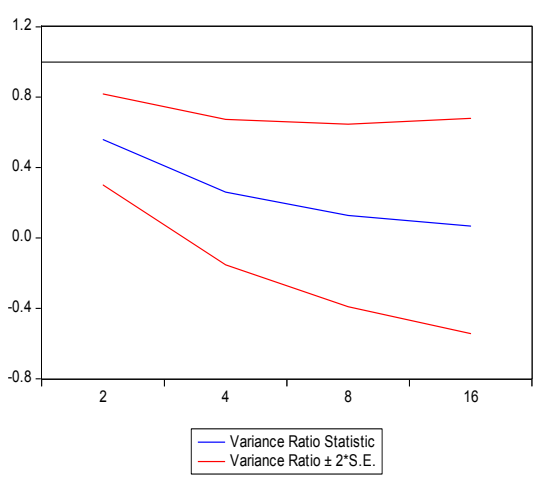

Sub-sample 2 (Returns)

Figure 7. Variance ratio plots for random walk

Table 10. Residual serial correlation and heteroskedasticity

\begin{tabular}{|c|c|c|c|c|c|}
\hline & \multirow[t]{2}{*}{ Lag order } & \multicolumn{2}{|c|}{ Breusch-Godfrey LM Test } & \multicolumn{2}{|c|}{ ARCH LM Tests } \\
\hline & & Log Level & Returns & Log Level & Returns \\
\hline \multirow{6}{*}{ Whole } & \multirow{2}{*}{1} & 1.6939 & $3.1410^{*}$ & 0.0235 & 0.0001 \\
\hline & & $(0.193)$ & $(0.077)$ & $(0.878)$ & $(0.992)$ \\
\hline & \multirow{2}{*}{2} & $2.3203 *$ & $2.7829^{*}$ & 0.0125 & 0.0007 \\
\hline & & $(0.099)$ & $(0.062)$ & $(0.988)$ & $(0.999)$ \\
\hline & \multirow{2}{*}{4} & 1.8110 & 1.5906 & 0.0064 & 0.0005 \\
\hline & & $(0.124)$ & $(0.175)$ & $(1.000)$ & $(1.000)$ \\
\hline \multirow{6}{*}{ Sub-sample 1} & \multirow{2}{*}{1} & $14.4757 * * *$ & 0.0578 & $13.2936^{* * *}$ & $29.0585^{* * *}$ \\
\hline & & $(0.000)$ & $(0.810)$ & $(0.000)$ & $(0.000)$ \\
\hline & \multirow{2}{*}{2} & $7.2950^{* * *}$ & $3.9441 * *$ & $6.6210^{* * *}$ & $14.4785^{* * *}$ \\
\hline & & $(0.000)$ & $(0.020)$ & $(0.002)$ & $(0.000)$ \\
\hline & \multirow{2}{*}{4} & $5.4645 * * *$ & $2.0204 *$ & $43.7898 * * *$ & $47.8741^{* * *}$ \\
\hline & & $(0.000)$ & $(0.091)$ & $(0.000)$ & $(0.000)$ \\
\hline \multirow{6}{*}{ Sub-sample 2} & \multirow{2}{*}{1} & $2.7794 *$ & 0.9986 & 0.3944 & 0.0015 \\
\hline & & $(0.096)$ & $(0.318)$ & $(0.530)$ & $(0.969)$ \\
\hline & \multirow{2}{*}{2} & 1.8867 & 0.6791 & 0.0497 & 0.3223 \\
\hline & & $(0.152)$ & $(0.507)$ & $(0.952)$ & $(0.968)$ \\
\hline & \multirow{2}{*}{4} & 1.0422 & 0.3943 & 0.0060 & 0.0038 \\
\hline & & $(0.385)$ & $(0.813)$ & (1.000) & $(1.000)$ \\
\hline
\end{tabular}

Note. Numbers in parentheses are F-statistics. $* * *, * * *$ Statistically significant at $1 \%, 5 \%$, and $10 \%$ level, respectively.

\section{Conclusion}

This paper has examines the price discovery mechanism at the DSE using basic econometric methods. These methods are based on fundamental and traditional tests for memory effects. The objective was to use the dynamic features of the DSE stock index and the deterministic features of the market to explain the efficiency of 
the price discovery mechanism. Specifically, we analyze the distribution of the index in relation to serial correlation, heteroskedasticity and normality as well as measuring for unit root and random walk. Our results, firstly, show strong evidence of non-normality in the index series with high level of leptokurtic distribution in returns. Secondly, both the index levels and returns appear to be stationary. Thirdly, the index appears to exhibit structural shifts, mainly associated with stock listings. Finally, there is evidence that the DSE stock index does not follow a random walk, suggesting inefficient price discovery (Fama, 1970), but not sufficient to conclude that the stock market itself is inefficient or that prices are not rational assessments of fundamental values (Lo \& MacKinlay, 1988). Further profound investigations are, therefore, crucial for achieving conclusive inferences.

On one hand, these results can be associated with some characteristic features of the exchange such as inactive trading, illiquidity and high dependence on foreign investors to boost market activities. On the other hand, they relate to the trading and investment behaviors of market participants such as investors' dependence on dividend as the main source of income rather than stock trading, uncompetitive trading among brokers, and motives for more returns from alternative portfolio investments in government securities. We call for policy makers at the DSE and the government to take further measures to improve market efficiency, especially stimulating more competition by amending regulations that limit competitive trading.

\section{Acknowledgements}

I warmly thank the Dar es Salaam Stock Exchange for its support on data. I also thank all those who provided valuable comments in shaping and improving this paper. I fully carry responsibility for any remaining errors.

\section{References}

Andrews, D. W. K. (1993). Tests for parameter instability and structural change with unknown change point. Econometrica, 61(4), 321-356. http://dx.doi.org/10.2307/2951764

Baillie, R. T. G., Booth, G. G., Tse, Y., \& Zabotina, T. (2002). Price discovery and common factor models. Journal of Financial Markets, 5(3), 309-321. http://dx.doi.org/10.1016/S1386-4181(02)00027-7

Beran, J. (1994). Statistics for Long memory Process. Chapman and Hall Publishing, Florida.

Bollerslev, T. (1986). Generalized Autoregressive Conditional Heteroskedasticity. Journal of Econometrics, 31(3), 307-327. http://dx.doi.org/10.1016/0304-4076(86)90063-1

Brogaard, J., Hendershott, T., \& Riordan, R. (2012). High Frequency trading and price discovery, Social Science Research Network (SSRN). Retrieved from http://ssrn.com/abstract=1928510

Business Times (2011, May). Foreign buyers crowding out locals from DSE shares sales. Business Times (Online edition). $\quad$ Retrieved from http://www.businesstimes.co.tz/index.php?option=com_content\&view=article\&id=1038:foreign-buyers-cro wding-out-locals-from-dse-shares-sales \&catid=40:marketandeconomy\&Itemid $=58$

Business Times. (2011, July). Capital markets sluggish as macroeconomic indicators sour. Business Times (Online edition). Retrieved from http://www.businesstimes.co.tz/index.php?option=com_content\&view=article\&id=1206:tanzania-capital-m arkets-sluggish-as-macroeconomic-indicators-sour\&catid=1:latest-news\&Itemid $=57$

Campbell, J. Y., Lo, A. W., \& MacKinlay, A. C. (1997). The Econometrics of Financial Markets. Princeton, New Jesse: Princeton University Press.

Chiwambo, Y. (2011, July). Depreciating shilling, power outages slow down activity at Dar stock mart. Business Times (Online edition). Retrieved from http://www.businesstimes.co.tz/index.php?option=com_content\&view=article\&id=1168:depreciating-shilli ng-power-outages-slow-down-activity-at-dar-stock-mart\&catid=1:latest-news\&Itemid=57

Chiwambo, Y. (2011, November). As Govt. paper gains momentum: equity market trading continues to be sluggish. Business Times (Online edition). Retrieved rom http://www.businesstimes.co.tz/index.php?option=com_content\&view=article\&id=1546:-as-govt-paper-gai ns-momentum\&catid=1:latest-news\&Itemid $=57$

Chiwambo, Y. (2011, October). Foreign investors restore life to DSE trading. Business Times (Online edition). Retrieved

from http://www.businesstimes.co.tz/index.php?option=com_content\&view=article\&id=1465:foreign-investors-r estore-life-to-dse-trading\&catid=40:marketandeconomy \&Itemid $=58$

Chiwango, A. (2012, October). TBL, CRDB Bank shine as foreign funds flow via DSE. Business Times (Online 
edition).

Retrieved

from

http://www.businesstimes.co.tz/index.php?option=com_content\&view=article\&id=2099:tbl-crdb-bank-shin e-as-foreign-funds-flow-via-dse \&catid $=1$ :latest-news\&Itemid $=57$

Chow, G. C. (1960). Tests of equality between sets of coefficients in two linear regressions. Econometrica, 28(3), 591-605. http://dx.doi.org/10.2307/1910133

Chow, K. V., \& Denning, K. C. (1993). A Simple Multiple Variance Ratio Test. Journal of Econometrics, 58(3), 385-401. http://dx.doi.org/10.1016/0304-4076(93)90051-6

Chuwa, H. (2011, July). Eight-in-ten investors in equity are largely uninformed. Business Times (Online edition). Retrieved from http://www.businesstimes.co.tz/index.php?option=com_content\&view=article\&id=1198:tanzania-eight-in-t en-investors-in-equity-are-largely-uninformed \&catid=40:marketandeconomy\&Itemid $=58$

Dharmanesa, K. A. S. D. B., \& Bessler, D. A. (2004). Weak-Form Efficiency Vs. Semi-Strong Form Efficiency in Price Discovery: an Application to International Black Tea Markets. Sri Lankan Journal of Agricultural Economics, 6(1), 1-24.

Dionisio, A., Menezes, R., \& Mendes, D. A. (2007). On the integrated behaviour of non-stationary volatility in stock markets. Physica, 382(1), 58-65. http://dx.doi.org/10.1016/j.physa.2007.02.008

DSE. (2010). Dar es Salaam Stock Exchange. Handbook.

Elinaza, A. (2011). CRDB Bank shares most traded at DSE. Daily News, Dar es Salaam.

Elinaza, A. (2012, April). Dar es Salaam bourse records low trade on flat counters. Daily News (Online edition). Retrieved from http://allafrica.com/stories/201204231367.html

Elinaza, A. (2012, April). Dividends push up Dar es salaam bourse trade. Daily News (Online edition). Retrieved from http://allafrica.com/stories/201204231367.html

Elinaza, A. (2012, April). Stockbrokers blamed for creating 'fake' liquidity. Daily News (Online edition). Retrieved from http://allafrica.com/stories/201204240184.html

Elinaza, A. (2012, April). Stockbrokers push for law review. Daily News (Online edition). Retrieved from http://allafrica.com/stories/201204240158.html

Elinaza, A. (2012, February). Trading to pick up on dse as yields on T-Bills dwindle. Daily News (Online edition). Retrieved from http://allafrica.com/stories/201202210804.html

Elinaza, A. (2013, December). Cross-listed shares seem dormant at Dar bourse. Daily News (Online edition). Retrieved from http://dailynews.co.tz/index.php/biz/14350-cross-listed-shares-seen-dormant-at-dar-bourse

Engle, R. F. (1982). Autoregressive Conditional Heteroskedasticity with Estimates of the variance of U.K Inflation. Econometrica, 50(4), 987-1008. http://dx.doi.org/10.2307/1912773

Fama, E. F. (1965). Random walk in stock market prices. Financial Analyst Journal, 21(5), 55-59. http://dx.doi.org/10.2469/faj.v21.n5.55

Fama, E. F. (1970). Efficient capital markets: a review of theory and empirical work. The Journal of Finance, 25(2), 383-417. http://dx.doi.org/10.2307/2325486

Fama, E. F. (1998). Market efficiency, long-term returns, and behavioral finance. Journal of Financial Economics, 49, 283-306. http://dx.doi.org/10.1016/S0304-405X(98)00026-9

Fong, W. M., Koh, S. K., \& Ouliaris, S. (1997). Joint Variance-Ratio Tests of the Martingale Hypothesis for Exchange Rates. Journal of Business and Economic Statistics, 15, 51-59.

Godfrey, L. G. (1988). Specification Tests in Econometrics. Cambridge: Cambridge University Press. http://dx.doi.org/10.1017/CCOL0521266165

Hansen, B. E. (2001). The econometrics of structural changes: dating breaks in U.S labor productivity. Journal of Economic Perspectives, 15(4), 117-128. http://dx.doi.org/10.1257/jep.15.4.117

Hausbouck, J. (1995). One security, many markets: determining the contributions to price discovery. The Journal of Finance, 50(4), 1175-1199. http://dx.doi.org/10.1111/j.1540-6261.1995.tb04054.x

Inclan, C., \& Tiao, G. C. (1994). Use of cumulative sums of squares for retrospective detection of change of variance. Journal of the American Statistics Association, 89, 913-923.

Johansen, S. (1988). Statistical Analysis of Cointegration Vectors. Journal of Economic Dynamics and Control, 


\section{2, 231-254. http://dx.doi.org/10.1016/0165-1889(88)90041-3}

Johansen, S. (1991) Estimation and Hypothesis Testing of Cointegration Vectors in Gaussian Vector Autoregressive Models. Econometrica, 59, 1551-1580. http://dx.doi.org/10.2307/2938278

Lehmann, B. N. (2002). Some desiderata for the measurement of price discov- ery across markets. Journal of Financial Markets, 5, 259-276. http://dx.doi.org/10.1016/S1386-4181(02)00025-3

Lo, A. W., \& Craig, M. (1989). The Size and Power of the Variance Ratio Test in Finite Samples. Journal of Econometrics, 40, 203-238. http://dx.doi.org/10.1016/0304-4076(89)90083-3

Lo, A. W., \& MacKinlay, A. C. (1988). Stock Market Prices Do Not Follow Random Walks: Evidence From a Simple Specification Test. The Review of Financial Studies, 1, 41-66. http://dx.doi.org/10.1093/rfs/1.1.41

Lorie, J. H., \& Hamilton, M. T. (1973). The Stock Market: Theories and Evidence. Home wood.

Mbani, M. (2011, March). DSE trading slows as investors hold shares, Business Times (Online edition). Retrieved

from http://www.businesstimes.co.tz/index.php?option=com_content\&view=article\&id=843:dse-trading-slows-a s-investors-hold-shares\&catid=40:marketandeconomy\&Itemid $=58$

Mrindoko, S. (2012, April). Banks shine at Dar es Salaam bourse, Daily News (Online edition). http://allafrica.com/stories/201203080058.html

O'Hara, M. (2003). Liquidity and Price Discovery. The Journal of Finance, 58, 1335-1354. http://dx.doi.org/10.1111/1540-6261.00569

Perron, P. (1989). The great crash, the oil price shock, and the unit root hypothesis. Econometrica, 57(6), 13611401. http://dx.doi.org/10.2307/1913712

Quandt, R. (1960). Tests of hypothesis that a linear regression obeys two separate regimes. Journal of The American Statistical Association, 55, 324-330. http://dx.doi.org/10.1080/01621459.1960.10482067

Rutabingwa, F. (2011). How CRDB shares provide a lifeline to DSE trading activities. The Citizen, Dar es Salaam.

Schreiber, P. S., \& Schwartz, R. A., (1986). Price discovery is securities markets. Journal of Portfolio Management, 12(4), 43-48. http://dx.doi.org/10.3905/jpm.1986.409071

Smith, D. R. (2008). Testing for structural breaks in GARCH models. Applied Financial Economics, 18, 845864. http://dx.doi.org/10.1080/09603100701262800

Wang, P. (2003). Financial Econometrics: methods and models. Routledge, London.

\section{Copyrights}

Copyright for this article is retained by the author(s), with first publication rights granted to the journal.

This is an open-access article distributed under the terms and conditions of the Creative Commons Attribution license (http://creativecommons.org/licenses/by/3.0/). 